Agropedology 2018, 28 (01), 70-74

\title{
Effect of Different Levels of Nitrogen and Sulphur on Yield and Nutrient Uptake by Fennel (Foeniculum vulgare Mill.)
}

\author{
H.C. Kucha, H.L. Sakarvadia, L.C. Vekaria* and K.B. Parmar \\ Department of Agricultural Chemistry and Soil Science, Junagadh Agricultural University, \\ Junagadh-362001, Gujarat, India
}

\begin{abstract}
An experiment comprising of four levels of nitrogen viz., 0, 60, 90 and 120 $\mathrm{kg} \mathrm{ha}^{-1}$ and three levels of sulphur viz., 0,20 and $40 \mathrm{~kg} \mathrm{ha}^{-1}$ was conducted in a factorial randomized block design, replicated thrice during rabi 2016-17 at the Instructional Farm, Department of Agronomy, College of Agriculture, Junagadh Agricultural University, Junagadh to study the influence of $\mathrm{N}$ and $\mathrm{S}$ on yield and uptake of nutrients by fennel. The experimental medium deep black soil was clay in texture and had pH 8.06 and EC $0.41 \mathrm{dSm}^{-1}$. Application of nitrogen@ $120 \mathrm{~kg} \mathrm{ha}^{-1}$ and $40 \mathrm{~kg} \mathrm{~S}$ $\mathrm{ha}^{-1}$ individually had significant effect on yield and uptake of N, P, K, S, Fe, Mn, Zn and $\mathrm{Cu}$ by seed and stover. Application of $90 \mathrm{~kg} \mathrm{~N}^{-1}$ with $40 \mathrm{~kg} \mathrm{~S}^{-1}$ produced significantly higher seed and stover yield than the other treatments.
\end{abstract}

Keywords : Fennel, nitrogen, sulphur, yield and nutrients uptake

\section{Introduction}

Fennel (Foeniculum vulgare), is an important seed spice, a native of southern Europe and Mediterranean area. It is commonly known as Saunf or Badi-saunf and in Gujarat it is locally known as Variari. The plant is pleasantly aromatic and is used as a pot herb. The seeds are aromatic, stimulant and carminative.

Nitrogen plays an important role in synthesis of chlorophyll and amino acids that contribute to the building unit of protein and thus growth of plants. An adequate supply of $\mathrm{N}$ is associated with vigorous vegetative growth and dark green colour and it plays an important role in the synthesis of the plant constituents through the action of different enzymes (Jones et al. 1991).In Fennel, sulphur is the fourth major plant nutrient after nitrogen, phosphorus and potassium and it helps in the synthesis of amino acids, proteins, oils, vitamins, enzymes and chlorophyll. The need for sulphur has also been identified because of the increased use of S-free fertilizers and higher productivity of crops associated with higher uptake of sulphur (Ponkia et al. 2018). Keeping in view the role of $N$ and $S$ in the biosynthesis of different organics, influencing the productivity of funnel, the present study was undertaken.

\section{Materials and Methods}

A field experiment was conducted on fennel (var. Gujarat Fennel-11) at instructional farm, Junagadh Agricultural University, during rabi season of 2016-17 in factorial randomized block design with four levels of nitrogenviz.,0, 60, 90 and $120 \mathrm{~kg} \mathrm{ha}^{-1}$ and three levels of sulphur viz., 0, 20 and $40 \mathrm{~kg} \mathrm{ha}^{-1}$ and treatments were replicated thrice.The experimental soil was clay in texture and slightly alkaline $(\mathrm{pH} 8.06)$ with EC $\left(0.41 \mathrm{dSm}^{-1}\right)$, medium in available nitrogen $\left(262 \mathrm{~kg} \mathrm{ha}^{-1}\right)$, phosphorus $\left(29 \mathrm{~kg} \mathrm{P}_{2} \mathrm{O}_{5} \mathrm{ha}^{-1}\right)$, potassium (218 $\left.\mathrm{kg} \mathrm{K}_{2} \mathrm{O} \mathrm{ha}^{-1}\right)$, sulphur (10.64 $\left.\mathrm{mg} \mathrm{kg}^{-1}\right)$, iron (5.24

*Corresponding author: (Email: lalit@jau.in) 
$\left.\mathrm{mg} \mathrm{kg}{ }^{-1}\right)$, zinc $\left(0.74 \mathrm{mg} \mathrm{kg}^{-1}\right)$, high in manganese (15.84 $\left.\mathrm{mg} \mathrm{kg}{ }^{-1}\right)$ and copper $\left(1.40 \mathrm{mg} \mathrm{kg}^{-1}\right)$.A basal dose of 30 $\mathrm{kg} \mathrm{P}_{2} \mathrm{O}_{5}$ was applied. The crop was harvested at 146 days after sowing.

The representative plant and seed samples from each plot was oven dried at $60{ }^{\circ} \mathrm{C}$ for 24 hours and then powdered. The known quantities of powdered samples were digested in a diacid mixture as per method described by Johnson and Ulrich (1969). The acid extract was used for the determination of phosphorus, potassium, sulphur, iron, zinc, manganese and copper. The nitrogen from plant samples were estimated by micro Kjeldahl method as described by A.O.A.C (1975). The phosphorus was determined by Vanadomolybdo phosphoric yellow colour method and potassium by flame photometer as described by Jackson (1974); sulphuras per the method developed by Williams and Steinbergs (1959). Micronutrient cations were estimated by Atomic Absorption Spectrophotometer (AAS) as described by Lindsay and Norvell (1978). Uptake of the nutrients by plant is based on yield and concentration in respective plant parts.

\section{Results and Discussion}

\section{Effect of nitrogen}

The data (Table 1) revealed that different levels of nitrogen had significant influence on seed and stover yield. Application of $120 \mathrm{~kg} \mathrm{Nha}^{-1}$ produced significantly higher seed (1826 kg ha ${ }^{-1}$ ) and stover (3583 $\left.\mathrm{kg} \mathrm{ha}^{-1}\right)$ yield and it was remain statistically at par with $90 \mathrm{~kg} \mathrm{~N} \mathrm{ha}^{-1}$. The present findings are in the conformity of those reported by Pratap et al. (2003) and Bhardwaj and Kumar(2016).

Application of different levels of nitrogen had significant effect on N, P, K, S, Fe, Mn, and $\mathrm{Zn}$ and $\mathrm{Cu}$ uptake by seed and stover of fennel. The application of $120 \mathrm{~kg}$ nitrogen $\mathrm{ha}^{-1}$ resulted in significantly higher uptake of nitrogen, phosphorus, potassium and sulphur to the tune of $50.84,3.92,8.52$ and $5.82 \mathrm{~kg} \mathrm{ha}^{-1}$ by seed (Table 3) and 34.21, 10.04, 20.4and $35.45 \mathrm{~kg}^{-1} \mathrm{ha}^{-1}$ stover (Table 4), respectively. Significantly higher uptakes of $\mathrm{Fe}, \mathrm{Mn}, \mathrm{Zn}$ and $\mathrm{Cu}$ uptake 250, 40.22, 76.84 and 43.30g ha ${ }^{-1}$ by seed (Table 5) and 255, 131, 60.31 and
$47.17 \mathrm{~g} \mathrm{ha}^{-1}$ by stover (Table 6) were also observed with application of $120 \mathrm{~kg}$ nitrogen $\mathrm{ha}^{-1}$, respectively. This might be attributed to higher availability of nutrients in root zone and enhanced metabolic activity at the cellular level. The results of present investigation are in agreements with the findings of Patel et al. (2000) and Mehta etal. (2011).

\section{Effect of sulphur}

Application of sulphur significantly influenced the seed and stover yield of fennel (Table 1). Significantly higher seed (1949 $\left.\mathrm{kg} \mathrm{ha}^{-1}\right)$ and stover (3751 $\mathrm{kg} \mathrm{ha}^{-1}$ ) yield were found with application of $40 \mathrm{~kg} \mathrm{~S} \mathrm{ha}$ ${ }^{1}$. The increase in seed yield with increasing levels of sulphur might be due to increased photosynthesis via better development and thickening of xylem and collenchymas tissues. Pratap et al. (2003) also reported similar findings in fennel.

Application of sulphur significantly affected the uptake of macro (Table 3) and micronutrients (Table 4) by seed and stover of fennel. Application of $40 \mathrm{~kg} \mathrm{~S}$ $\mathrm{ha}^{-1}$ recorded significantly higher uptake of nitrogen, phosphorus, potassium and sulphur to the magnitude of $47.19,4.14,8.93$ and $6.59 \mathrm{~kg} \mathrm{ha}^{-1}$ by seed (Table 3) and $31.21,10.60,21.4$ and $40.78 \mathrm{~kg} \mathrm{ha}^{-1}$ by stover (Table 4), respectively. Similarly, significantly higher uptakes of $\mathrm{Fe}, \mathrm{Mn}, \mathrm{Zn}$ and $\mathrm{Cu}$ i.e. $277,40.44,81.70$ and $46.57 \mathrm{~g}$ ha ${ }^{1}$ by seed (Table 5) and 263, 134, 63.02 and $47.44 \mathrm{~g} \mathrm{ha}^{-1}$ by stover (Table 6) were also observed with the application of $40 \mathrm{~kg} \mathrm{Sha}{ }^{-1}$ owing to its influence on growth and yield attributes of crop. These findings are in agreement with those reported by Pratap et al. (2003).

\section{Interaction effect}

The interaction between nitrogen and sulphur application on seed and stover yield was found significant (Table 2). Application of $90 \mathrm{~kg} \mathrm{~N} \mathrm{ha}^{-1}$ along with $40 \mathrm{~kg} \mathrm{~S} \mathrm{ha}^{-1}$ recorded significantly higher seed $\left(2158 \mathrm{~kg} \mathrm{ha}^{-1}\right)$ and stover(4194kg ha $\left.{ }^{-1}\right)$ yield than other treatments. However, it was statistically comparable with treatment $\mathrm{N}_{60} \mathrm{~S}_{40}$ and $\mathrm{N}_{120} \mathrm{~S}_{40}$. The present findings are in close agreement with the results obtained by Pratap et al. (2003). 
Table 1.Effect of different levels of nitrogen and sulphur on yield of fennel

\begin{tabular}{|c|c|c|}
\hline Treatments & $\begin{array}{c}\text { Seed yield } \\
\left(\mathrm{kg} \mathrm{ha}^{-1}\right)\end{array}$ & $\begin{array}{l}\text { Stover yield } \\
\left(\mathrm{kg} \mathrm{ha}^{-1}\right)\end{array}$ \\
\hline \multicolumn{3}{|l|}{ Nitrogen levels $\left(\mathrm{kg} \mathrm{N} \mathrm{ha}^{-1}\right)$} \\
\hline $\mathrm{N}_{0}($ Control $)$ & 1400 & 2738 \\
\hline $\mathrm{N}_{60}$ & 1666 & 3288 \\
\hline $\mathrm{N}_{90}$ & 1774 & 3481 \\
\hline $\mathrm{N}_{120}$ & 1826 & 3583 \\
\hline S.Em \pm & 45 & 84 \\
\hline C.D. at $5 \%$ & 131 & 248 \\
\hline \multicolumn{3}{|l|}{ Sulphur levels (kg S ha-1) } \\
\hline $\mathrm{S}_{0}($ Control $)$ & 1443 & 2898 \\
\hline $\mathrm{S}_{20}$ & 1607 & 3169 \\
\hline $\mathrm{S}_{40}$ & 1949 & 3751 \\
\hline S.Em \pm & 39 & 73 \\
\hline C.D. at $5 \%$ & 114 & 214 \\
\hline \multicolumn{3}{|l|}{ Interaction (N x S) } \\
\hline S.Em.. \pm & 77 & 146 \\
\hline C.D. at $5 \%$ & 227 & 429 \\
\hline C.V.\% & 8.10 & 7.70 \\
\hline
\end{tabular}

Table 2.Interaction effect of nitrogen and sulphur on seed and stover yield of fennel

\begin{tabular}{|c|c|c|c|c|c|c|c|c|}
\hline \multirow{3}{*}{$\begin{array}{l}\text { Levels of } \\
\text { Nitrogen }\end{array}$} & \multicolumn{8}{|c|}{ Levels of sulphur } \\
\hline & \multicolumn{4}{|c|}{ Seed yield $\left(\mathrm{kg} \mathrm{ha}^{-1}\right)$} & \multicolumn{4}{|c|}{ Stover yield $\left(\mathrm{kg} \mathrm{ha}^{-1}\right)$} \\
\hline & $\mathbf{S}_{\mathbf{0}}$ & $\mathbf{S}_{20}$ & $\mathbf{S}_{40}$ & Mean & $\mathbf{S}_{\mathbf{0}}$ & $\mathbf{S}_{\mathbf{2 0}}$ & $\mathbf{S}_{40}$ & Mean \\
\hline $\mathrm{N}_{0}$ & 1332 & 1382 & 1487 & 1400 & 2614 & 2808 & 2794 & 2738 \\
\hline $\mathrm{N}_{60}$ & 1362 & 1619 & 2017 & 1666 & 2792 & 3148 & 3925 & 3288 \\
\hline $\mathrm{N}_{90}$ & 1488 & 1675 & 2158 & 1774 & 2975 & 3276 & 4194 & 3481 \\
\hline $\mathrm{N}_{120}$ & 1591 & 1754 & 2132 & 1826 & 3211 & 3444 & 4093 & 3583 \\
\hline Mean & 1443 & 1607 & 1949 & & 2898 & 3169 & 3751 & \\
\hline $\mathrm{S} . \mathrm{Em} \pm$ & \multicolumn{4}{|c|}{77} & \multicolumn{4}{|c|}{146} \\
\hline C.D. at $5 \%$ & \multicolumn{4}{|c|}{227} & \multicolumn{4}{|c|}{429} \\
\hline
\end{tabular}

Table 3.Effect of different levels of nitrogen and sulphur on N, P, K and S uptake by seed of fennel

\begin{tabular}{lcccc}
\hline \multirow{2}{*}{ Treatments } & \multicolumn{4}{c}{ Uptake by seed $\left(\mathbf{k g ~ h a}^{-\mathbf{1}}\right)$} \\
\cline { 2 - 4 } & $\mathbf{N}$ & $\mathbf{P}$ & $\mathbf{K}$ & $\mathbf{S}$ \\
\hline Nitrogen levels (kg N ha $)$ & & & & \\
$\mathrm{N}_{0}$ (Control) & 25.79 & 2.92 & 6.24 & 4.40 \\
$\mathrm{~N}_{60}$ & 37.89 & 3.65 & 7.63 & 5.31 \\
$\mathrm{~N}_{90}$ & 45.74 & 3.78 & 8.37 & 5.70 \\
$\mathrm{~N}_{120}$ & 50.84 & 3.92 & 8.52 & 5.82 \\
S.Em \pm & 1.86 & 0.15 & 0.28 & 0.23 \\
C.D. at 5\% & 5.45 & 0.44 & 0.81 & 0.69 \\
Sulphur levels (kg S ha $\left.{ }^{-1}\right)$ & & & \\
$\mathrm{S}_{0}$ - (Control) & 33.93 & 3.06 & 6.76 & 4.11 \\
$\mathrm{~S}_{20}$ & 39.07 & 3.51 & 7.37 & 5.22 \\
$\mathrm{~S}_{40}$ & 47.19 & 4.14 & 8.93 & 6.59 \\
S.Em \pm & 1.61 & 0.13 & 0.24 & 0.20 \\
C.D. at 5\% & 4.72 & 0.380 & 0.701 & 0.60 \\
Interaction (N x S) & & & \\
S.Em. \pm & 3.22 & 0.26 & 0.48 & 0.41 \\
C.D. at 5\% & $\mathrm{NS}$ & $\mathrm{NS}$ & $\mathrm{NS}$ & $\mathrm{NS}$ \\
C.V.\% & 13.91 & 12.58 & 10.77 & 13.23 \\
\hline
\end{tabular}


Table 4.Effect of different levels of nitrogen and sulphur on uptake of N, P, K and S by stover

\begin{tabular}{|c|c|c|c|c|}
\hline \multirow[t]{2}{*}{ Treatments } & \multicolumn{4}{|c|}{ Uptake by stover $\left(\mathrm{kg} \mathrm{ha}^{-1}\right)$} \\
\hline & $\mathbf{N}$ & $\mathbf{P}$ & $\mathbf{K}$ & $\mathbf{S}$ \\
\hline \multicolumn{5}{|c|}{ Nitrogen levels $\left(\mathrm{kg} \mathrm{N} \mathrm{ha}^{-1}\right)$} \\
\hline $\mathrm{N}_{0}($ Control $)$ & 17.87 & 7.63 & 15.6 & 27.43 \\
\hline $\mathrm{N}_{60}$ & 24.98 & 9.27 & 18.6 & 33.00 \\
\hline $\mathrm{N}_{90}$ & 31.10 & 10.00 & 19.9 & 35.16 \\
\hline $\mathrm{N}_{120}$ & 34.21 & 10.04 & 20.4 & 35.45 \\
\hline S.Em \pm & 1.01 & 0.43 & 0.90 & 1.44 \\
\hline C.D. at $5 \%$ & 2.96 & 1.27 & 2.64 & 4.23 \\
\hline \multicolumn{5}{|c|}{ Sulphur levels $\left(\mathrm{kg} \mathrm{S}^{-1}\right)$} \\
\hline $\mathrm{S}_{0}($ Control $)$ & 23.81 & 8.20 & 16.5 & 24.87 \\
\hline $\mathrm{S}_{20}$ & 26.09 & 8.90 & 18.0 & 32.62 \\
\hline $\mathrm{S}_{40}$ & 31.21 & 10.60 & 21.4 & 40.78 \\
\hline $\operatorname{S.Em} \pm$ & 0.87 & 0.38 & 0.78 & 1.25 \\
\hline C.D. at $5 \%$ & 2.56 & 1.10 & 2.29 & 3.66 \\
\hline \multicolumn{5}{|l|}{ Interaction (N x S) } \\
\hline S.Em. \pm & 1.75 & 0.75 & 1.56 & 2.50 \\
\hline C.D. at $5 \%$ & NS & NS & NS & NS \\
\hline C.V.\% & 11.19 & 14.11 & 14.50 & 13.21 \\
\hline
\end{tabular}

Table 5.Effect of different levels of nitrogen and sulphur on uptake of $\mathrm{Fe}, \mathrm{Mn}, \mathrm{Zn}$ and Cuby seed

\begin{tabular}{|c|c|c|c|c|}
\hline \multirow[t]{2}{*}{ Treatments } & \multicolumn{4}{|c|}{ Uptake by seed $\left(\mathrm{g} \mathrm{ha}^{-1}\right)$} \\
\hline & $\mathbf{F e}$ & Mn & $\mathbf{Z n}$ & $\mathbf{C u}$ \\
\hline \multicolumn{5}{|c|}{ Nitrogen levels $\left(\mathrm{kg} \mathrm{N} \mathrm{ha}^{-1}\right)$} \\
\hline $\mathrm{N}_{0}($ Control $)$ & 194 & 28.78 & 56.99 & 29.46 \\
\hline $\mathrm{N}_{60}$ & 237 & 33.91 & 69.17 & 37.73 \\
\hline $\mathrm{N}_{90}$ & 252 & 36.87 & 73.87 & 42.34 \\
\hline $\mathrm{N}_{120}$ & 250 & 40.22 & 76.84 & 43.30 \\
\hline $\operatorname{S.Em} \pm$ & 8 & 1.30 & 2.19 & 1.87 \\
\hline C.D. at $5 \%$ & 24 & 3.82 & 6.44 & 5.47 \\
\hline \multicolumn{5}{|c|}{ Sulphur levels $\left(\mathrm{kg} \mathrm{S} \mathrm{ha}^{-1}\right)$} \\
\hline $\mathrm{S}_{0}($ Control $)$ & 199 & 30.54 & 58.97 & 31.81 \\
\hline $\mathrm{S}_{20}$ & 223 & 33.86 & 66.98 & 37.24 \\
\hline $\mathrm{S}_{40}$ & 277 & 40.44 & 81.70 & 46.57 \\
\hline $\mathrm{S} . \mathrm{Em} \pm$ & 7 & 1.13 & 1.90 & 1.62 \\
\hline C.D. at $5 \%$ & 21 & 3.31 & 5.37 & 4.74 \\
\hline \multicolumn{5}{|l|}{ Interaction (N x S) } \\
\hline S.Em. \pm & 14 & 2.26 & 3.80 & 3.23 \\
\hline C.D. at $5 \%$ & NS & NS & NS & NS \\
\hline C.V.\% & 10.72 & 11.19 & 9.51 & 14.65 \\
\hline
\end{tabular}


Table 6.Effect of different levels of nitrogen and sulphur on uptake of $\mathrm{Fe}, \mathrm{Mn}, \mathrm{Zn}$ and $\mathrm{Cu}$ ) by stover of fennel

\begin{tabular}{|c|c|c|c|c|}
\hline \multirow[t]{2}{*}{ Treatments } & \multicolumn{4}{|c|}{ Uptake by stover ( $\left.\mathrm{g} \mathrm{ha}^{-1}\right)$} \\
\hline & $\mathrm{Fe}$ & Mn & $\mathbf{Z n}$ & $\mathbf{C u}$ \\
\hline \multicolumn{5}{|c|}{ Nitrogen levels $\left(\mathrm{kg} \mathrm{N} \mathrm{ha}^{-1}\right)$} \\
\hline $\mathrm{N}_{0}$ (Control) & 189 & 102 & 45.18 & 36.05 \\
\hline $\mathrm{N}_{60}$ & 228 & 118 & 54.49 & 42.59 \\
\hline $\mathrm{N}_{90}$ & 239 & 122 & 58.30 & 44.36 \\
\hline $\mathrm{N}_{120}$ & 255 & 131 & 60.31 & 47.17 \\
\hline $\mathrm{S} . \mathrm{Em} \pm$ & 9 & 6 & 2.11 & 1.59 \\
\hline C.D. at $5 \%$ & 25 & 16 & 6.19 & 4.67 \\
\hline \multicolumn{5}{|c|}{ Sulphur levels $\left(\mathrm{kg} \mathrm{S} \mathrm{h}^{-1}\right)$} \\
\hline $\mathrm{S}_{0}$ (Control) & 200 & 103 & 48.47 & 37.57 \\
\hline $\mathrm{S}_{20}$ & 220 & 117 & 52.23 & 42.62 \\
\hline $\mathrm{S}_{40}$ & 263 & 134 & 63.02 & 47.44 \\
\hline $\mathrm{S} . \mathrm{Em} \pm$ & 7 & 5 & 1.83 & 1.38 \\
\hline C.D. at $5 \%$ & 22 & 14 & 5.36 & 4.04 \\
\hline \multicolumn{5}{|c|}{ Interaction $(\mathrm{N} \times \mathrm{S})$} \\
\hline S.Em. \pm & 15 & 10 & 3.65 & 2.76 \\
\hline C.D. at $5 \%$ & NS & NS & NS & NS \\
\hline C.V. $\%$ & 11.31 & 14.09 & 11.60 & 11.23 \\
\hline
\end{tabular}

\section{References}

A.O.A.C. (1975).Official Methods of Analysis (12 Edition) William Strawetgled. Published by A.O.A.C., Washington, DC, pp.506-508.

Bhardwaj, R.L., and Kumar, D. (2016). Effect of varying levels of nitrogen on growth, yield, quality and profitability of transplanted fennel (Foeniculum vulgare Mill.). Journal of Spices and Aromatic Crops 25, 141-148.

Jackson, M.L. (1974). Soil Chemical Analysis.Prentice Hall of India Pvt. Ltd., New Delhi, pp. 327-350.

Johnson, C.M., and Ulrich, A. (1969)."Analytical Method for Use in Plant Analysis".Bulletin, California Agric. Expt. Stn., 766.

Jones, I.B.,Wolf, B., and Milles, H.A. (1991). Methods of Elemental Analysis (Chapter- 4)In: Plant Analysis Handbook. Macro-Micro Publishing, Athens, Georgia. pp 27-38.

Lindsay, W.L., and Norvell, W.A.(1978).Development of a DTPA test for Zinc, Iron, Manganese and Copper. Soil Science Society of America Journal 42, 421-428.

Mehta, R.S., Anwer, M.M., and Aishwath, O.P. (2011). Growth and yield of fennel (Foeniculum vulgare
Mill.) as influenced by irrigation, nutrient levels and crop geometry. Journal of Spices and Aromatic Crops 20, 77-80.

Patel, B.S., Patel, K.P., Pate, I.D., and Patel, M.I. (2000).Response of fennel (Foeniculum vulgare) to irrigation, nitrogen and phosphorus. Indian Journal of Agronomy 45, 429-432.

Ponkia H.P., Vekaria, L.C., Ramani, V.B., Sakrvadia, H.L., Polara K.B., and Babaria, N.B. (2018).Potassium and sulphur fertilization of wheat (Triticuma estivum L.) in medium black calcareous soils of Saurashtra Region of Gujarat. International Journal of Chemical Studies 6,1634-1640.

Pratap, R., Meena, N.L. and Yadav, G.L. (2003).Effect of nitrogen and sulphur on growth and yield of fennel. Annals of Arid Zone 42, 97-99.

Williams, C.H., and Steinbergs, A. (1959).Soil sulphur (Heat soluble sulphur or available sulphur) fractions as chemical indices of available sulphur in some Australian soils. Australian Journal of Agricultural Research 10, 340-352.

Received: February, 2018 Accepted: June, 2018 